\title{
Modulation of MMP-2 and -9 secretion by cytokines, inducers and inhibitors in human melanoma A-2058 cells
}

\author{
M. WAHEED ROOMI, TATIANA KALINOVSKY, ALEKSANDRA NIEDZWIECKI and MATTHIAS RATH
}

Dr. Rath Research Institute, 1260 Memorex Drive, Santa Clara, CA 95050, USA

Received January 12, 2017; Accepted April 3, 2017

DOI: $10.3892 /$ or.2017.5597

\begin{abstract}
Melanoma, an extremely aggressive cancer, causes the most skin cancer-related deaths, due to metastasis to other areas of the body, such as lymph nodes, lungs, liver, brain or bone. It is characterized by high levels of matrix metalloproteinase (MMP)-2 and -9 secretions that degrade the extracellular matrix and basement membrane, allowing cancer cells to spread to distal organs. Various cytokines, mitogens, growth factors, inducers and inhibitors control MMP activities. We investigated the roles of these in regulation of MMP-2 and -9 in human melanoma A-2058 cells. Human A-2058 cells were grown in DMEM supplemented with $15 \%$ FBS and antibiotics in 24-well tissue culture plates. At near confluence, the cells were washed with PBS and incubated in serum-free media with phorbol 12-myristate 13 -acetate (PMA) at 10, 25, 50 and $100 \mathrm{ng} / \mathrm{ml}$; TNF- $\alpha$ and IL-1 $\beta$ at $0.1,1,10$ and $25 \mathrm{ng} / \mathrm{ml}$; LPS at 10, 25, 50 and $100 \mu \mathrm{g} / \mathrm{ml}$; epigallocatechin gallate (EGCG) and doxycycline (Dox) at 10, 25, 50 and $100 \mu \mathrm{M}$ without and with PMA; a nutrient mixture (NM) containing lysine, proline, ascorbic acid and green tea extract without and with PMA at 10, 50, 100,500 and $1,000 \mu \mathrm{g} / \mathrm{ml}$; actinomycin D and cyclohexamide at 2 and $4 \mu \mathrm{M}$; retinoic acid and dexamethasone at $50 \mu \mathrm{M}$. After $24 \mathrm{~h}$ the media were removed and analyzed for MMP-2 and MMP-9 by zymography and densitometry. Melanoma A-2058 demonstrated strong expression of MMP-2 and slight expression of MMP-9. PMA at $100 \mathrm{ng} / \mathrm{ml}$ showed no effect on MMP-2 secretion but potently upregulated MMP-9 secretion to $400 \%$ that of control. TNF- $\alpha$ showed no significant overall effect on expression of MMP-2 but potent dose-dependent increased MMP-9 secretion with $200 \%$ of control at $25 \mathrm{ng} / \mathrm{ml}$. IL-1 $\beta$ showed no significant effect on MMP-2 or MMP-9 secretion by A-2058 cells, except at $25 \mathrm{ng} / \mathrm{ml}$ where MMP-2
\end{abstract}

Correspondence to: Dr Aleksandra Niedzwiecki, Dr. Rath Research Institute, 1260 Memorex Drive, Santa Clara, CA 95050, USA

E-mail: author@drrath.com

Key words: matrix metalloproteinases, melanoma A-2058, cytokines, inducers, inhibitors level was reduced by $\sim 40 \%$ and MMP-9 secretion 50\%. LPS treatment showed no significant effect on MMP-2 secretion and enhanced MMP-9 secretion up to $25 \mu \mathrm{g} / \mathrm{ml}$ followed by decreased level. EGCG, NM and doxycycline, without and with PMA, downregulated the expression of MMP-2 and MMP-9 in a dose-dependent manner. Actinomycin D, cyclohexamide and retinoic acid had inhibitory effects on MMP-2, while dexamethasone showed slight stimulatory effect on MMP-2 secretion. Our results showed that select cytokines, mitogens and inhibitors modulated A-2058 MMP-2 and MMP-9 expression. They suggest the clinical potential of MMP inhibitors, especially the non-toxic ones, such as the nutrient mixture and its component EGCG in management of melanoma.

\section{Introduction}

Cancer of the skin is by far the most common of all cancers. Melanoma accounts for only $\sim 1 \%$ of skin cancers but causes a large majority of skin cancer deaths, due to metastasis to other areas of the body, such as lymph nodes, lungs, liver, brain or bone. Though often curable in its early stages, metastatic malignant melanoma is an extremely aggressive cancer with no current viable treatment. The American Cancer Society estimates that 76,380 new melanomas will be diagnosed ( 46,870 in men and 29,510 in women) in the United States for 2016. Approximately 10,130 people are expected to die of melanoma ( $\sim 6,750$ men and 3,380 women). The rates of melanoma have been rising for the last 30 years (1).

Thus, any successful treatment for melanoma has to target metastasis, which is dependent upon degradation of the extracellular matrix (ECM), which, when intact, acts as a barrier to block cancer cell invasion (2-4). Clinical and experimental studies have demonstrated that elevated levels of matrix metalloproteinases are associated with rapid progression of metastatic melanoma $(5,6)$. MMP activity is regulated by and dependent upon environmental influences from surrounding stroma cells, ECM proteins, systemic hormones and other factors. Inflammation has been reported to drive cancer progression (7-9). Inflammatory cytokines such as interleukin (IL)-1 $\beta$ play significant roles in inflammation driven melanoma growth and progression (10). In the present study we investigated the effects of selected cytokines, inducers and inhibitors affecting cancer cell metabolism on the regulation of MMP-2 and MMP-9 activities in melanoma A-2058 cell line. 


\section{Materials and methods}

Materials. Human melanoma A-2058 cells were obtained from the American Type Culture Collection (ATCC; Rockville, MD, USA). Antibiotics, penicillin and fetal bovine serum (FBS), were obtained from Gibco-BRL (Long Island, NY, USA). Twenty-four well tissue culture plates were obtained from Corning Costar Corp. (Cambrdige, MA, USA). Gelatinase zymography was performed in $10 \%$ Novex pre-cast SDS polyacrylamide gel (Invitrogen) with $0.1 \%$ gelatin in non-reducing conditions. Interleukin $1 \beta$, tumor necrosis factor- $\alpha$ (TNF- $\alpha$ ), phorbol 12-myristate 13-acetate (PMA), lipopolysaccharide (LPS), doxycycline, epigallocatechin gallate (EGCG), actinomycin-D, cyclohexamide, retinoic acid and dexamethasone, were purchased from Sigma-Aldrich (St. Louis, MO, USA). The nutrient mixture (NM), prepared by VitaTech (Hayward, CA, USA) was composed of the following ingredients in the relative amounts indicated: Vitamin $\mathrm{C}$ (as ascorbic acid and as $\mathrm{Mg}$, Ca and palmitate ascorbate) $700 \mathrm{mg}$; L-lysine 1,000 mg; L-proline, $750 \mathrm{mg}$; L-arginine, $500 \mathrm{mg}$; N-acetyl cysteine, $200 \mathrm{mg}$; standardized green tea extract ( $80 \%$ polyphenol), 1,000 mg; selenium, $30 \mu \mathrm{g}$; copper, $2 \mathrm{mg}$; manganese, $1 \mathrm{mg}$. All other reagents used were of high quality and were obtained from Sigma-Aldrich, unless otherwise indicated.

Cell cultures. Melanoma cells were grown in Dulbecco's modified Eagle's medium (DMEM), supplemented with $15 \%$ FBS, $100 \mathrm{U} / \mathrm{ml}$ penicillin and $100 \mu \mathrm{g} / \mathrm{ml}$ streptomycin in 24-well tissue culture plates. The cells were plated at a density of $1 \times 10^{5}$ cells $/ \mathrm{ml}$ and grown to confluency in a humidified atmosphere at $5 \% \mathrm{CO}_{2}$ at $37^{\circ} \mathrm{C}$. Serum-supplemented media were removed and the cell monolayer was washed once with phosphate-buffered saline (PBS) and with the recommended serum-free media. The cells were then incubated in $0.5 \mathrm{ml}$ of serum-free medium with various cytokines, mitogens, inducers and inhibitors in triplicate, as indicated: PMA (10, 25, 50 and $100 \mathrm{ng} / \mathrm{ml})$; TNF- $\alpha$ and IL-1 $\beta$ (0.1, 1, 10 and $25 \mathrm{ng} / \mathrm{ml})$; LPS $(10,25,50$ and $100 \mu \mathrm{g} / \mathrm{ml})$; EGCG $(10,25,50$ and $100 \mu \mathrm{M})$ without and with PMA $100 \mathrm{ng} / \mathrm{ml}$; doxycycline $(10,25,50$ and $100 \mu \mathrm{M})$ without and with PMA $100 \mathrm{ng} / \mathrm{ml}$; NM (10, 50, $100,500$ and $1,000 \mu \mathrm{g} / \mathrm{ml})$ without and with PMA $100 \mathrm{ng} / \mathrm{ml}$, retinoic acid $(50 \mu \mathrm{M})$; dexamethasone $(50 \mu \mathrm{M})$; actinomycin D and cyclohexamide ( 2 and $4 \mu \mathrm{g} / \mathrm{ml})$. The plates were then returned to the incubator. The conditioned medium from each treatment was collected separately, pooled and centrifuged at $4^{\circ} \mathrm{C}$ for $10 \mathrm{~min}$ at 3,000 rpm to remove cells and cell debris. The clear supernatant was collected and used for gelatinase zymography, as described below.

Gelatinase zymography. Gelatinase zymography was utilized because of its high sensitivity to gelatinolytic enzymatic activity and ability to detect both pro and active forms of MMP-2 and MMP-9. Upon renaturation of the enzyme, the gelatinases digest the gelatin in the gel and reveal clear bands against an intensely stained background. Gelatinase zymography was performed in $10 \%$ Novex pre-cast SDS polyacrylamide gel in the presence of $0.1 \%$ gelatin under non-reducing conditions. Culture media $(20 \mu \mathrm{l})$ were mixed with sample buffer and loaded for SDS-PAGE with Tris-Glycine SDS buffer, as suggested by the manufacturer (Novex). Samples were not
Table I. Effect of inducers, cytokines and mitogens on melanoma A-2058 MMP-2 and MMP-9 secretion.

\begin{tabular}{|c|c|c|}
\hline Treatment & MMP-2 (\%) & MMP-9 (\%) \\
\hline \multicolumn{3}{|c|}{ PMA (ng/ml) } \\
\hline Control & 100 & 100 \\
\hline 10 & 92.2 & 100.9 \\
\hline 25 & 89.7 & 146.8 \\
\hline 50 & 94.6 & 288.5 \\
\hline 100 & 97.6 & 399.9 \\
\hline \multicolumn{3}{|c|}{ TNF- $\alpha(\mathrm{ng} / \mathrm{ml})$} \\
\hline Control & 100 & 100 \\
\hline 0.1 & 99.7 & 118.4 \\
\hline 1 & 99.7 & 118.4 \\
\hline 10 & 98.9 & 145.1 \\
\hline 25 & 97.8 & 204.2 \\
\hline \multicolumn{3}{|c|}{$\mathrm{IL}-1 \beta(\mathrm{ng} / \mathrm{ml})$} \\
\hline Control & 100 & 100 \\
\hline 0.1 & 118.3 & 99.8 \\
\hline 1 & 117.4 & 99.6 \\
\hline 10 & 122.1 & 99.7 \\
\hline 25 & 64.6 & 51.2 \\
\hline \multicolumn{3}{|c|}{$\mathrm{LPS}(\mu \mathrm{g} / \mathrm{ml})$} \\
\hline Control & 100 & 100 \\
\hline 10 & 93.3 & 172 \\
\hline 25 & 103 & 228 \\
\hline 50 & 106 & 200 \\
\hline 100 & 103 & 161 \\
\hline
\end{tabular}

boiled before electrophoresis. Following electrophoresis the gels were washed twice in $2.5 \%$ Triton X-100 for $30 \mathrm{~min}$ at room temperature to remove SDS. The gels were then incubated at $37^{\circ} \mathrm{C}$ overnight in substrate buffer containing $50 \mathrm{mM}$ Tris- $\mathrm{HCl}$ and $10 \mathrm{mM} \mathrm{CaCl}_{2}$ at $\mathrm{pH} 8.0$ and stained with $0.5 \%$ Coomassie Blue R250 in 50\% methanol and $10 \%$ glacial acetic acid for $30 \mathrm{~min}$ and destained. Protein standards were run concurrently and approximate molecular weights were determined by plotting the relative mobilities of known proteins. Gelatinase zymograms were scanned using CanoScan 9950F Canon scanner at 300 dpi. The intensity of the bands was evaluated using the pixel-based densitometer program Un-Scan-It, version 5.1, 32-bit, by Silk Scientific, Inc., (Orem, UT, USA), at a resolution of 1 Scanner Unit (1/100 of an inch for an image that was scanned at $100 \mathrm{dpi}$ ).

Statistical analysis. Microsoft Excel 2010 linear trend analysis was utilized to determine the linear trend analyses of the densitometry results.

\section{Results}

Inducers, mitogens and cytokines. Melanoma A-2058 expressed bands corresponding to MMP-2 and MMP-9. Table I shows the quantitative densitometry results from the effects of 

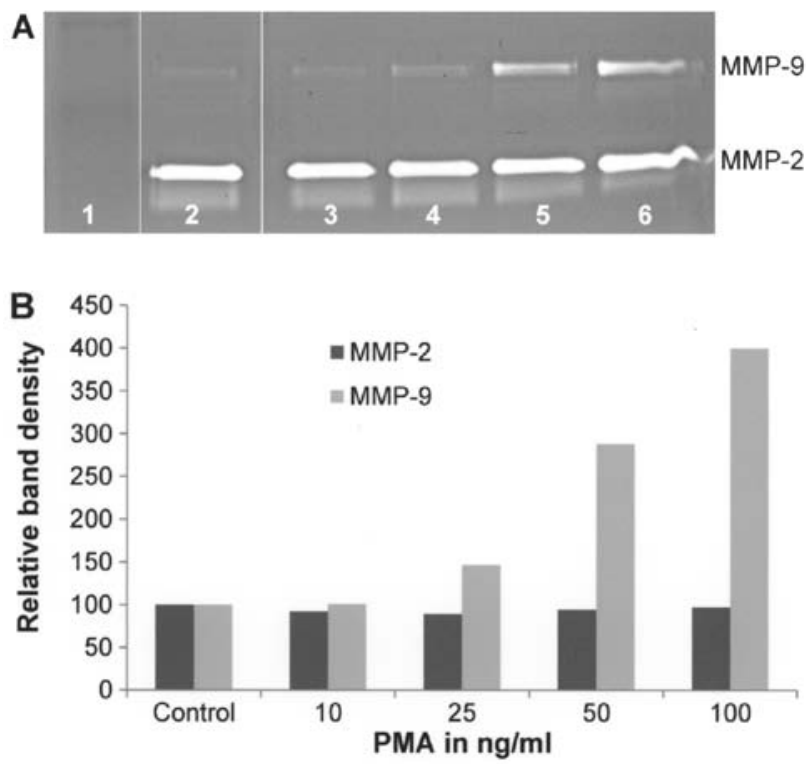

Figure 1. Effect of PMA on MMP-2 and -9 secretions in melanoma A-2058 cell line. (A) Gelatinase zymogram and (B) densitometry analysis of A-2058 MMP-2 and -9 expressions. Lane 1, markers; lane 2, Control; lanes 3-6 PMA $(10,25,50$ and $100 \mathrm{ng} / \mathrm{ml}$, respectively).
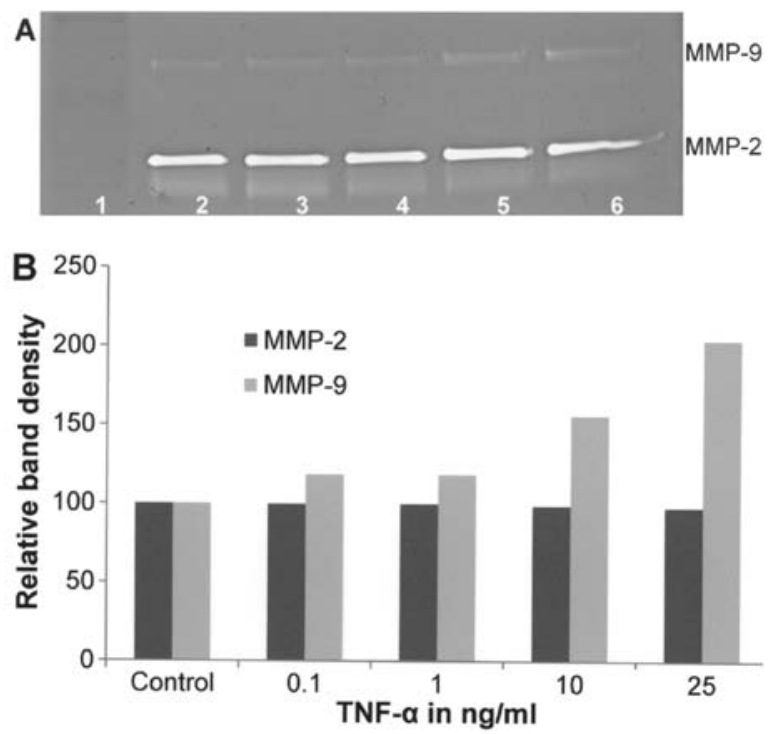

Figure 2. Effect of TNF- $\alpha$ on MMP-2 and -9 secretions in melanoma A-2058 cell line. (A) Gelatinase zymogram and (B) densitometry analysis of A-2058 MMP-2 and MMP-9 expressions. Lane 1, markers; lane 2, Control; lanes 3-6, TNF- $\alpha(0.1,1,10$ and $25 \mathrm{ng} / \mathrm{ml}$, respectively).

PMA, TNF- $\alpha$, IL-1 $\beta$ and LPS on MMP-2 and MMP-9 expression in A-2058 cells.

Effect of PMA on A-2058 cell secretion of MMPs. On gelatinase zymography, A-2058 demonstrated strong expression of MMP-2 and slight expression of MMP-9. PMA treatment ranging from concentrations of $10-100 \mathrm{ng} / \mathrm{ml}$ showed no significant effect on MMP-2 secretion (linear trend $\mathrm{R}^{2}=0.009$ ) but significant dose-dependent upregulation of MMP-9 secretion with $400 \%$ that of control at $100 \mathrm{ng} / \mathrm{ml}$ (linear trend $\mathrm{R}^{2}=0.883$ ) (Fig. 1).
A
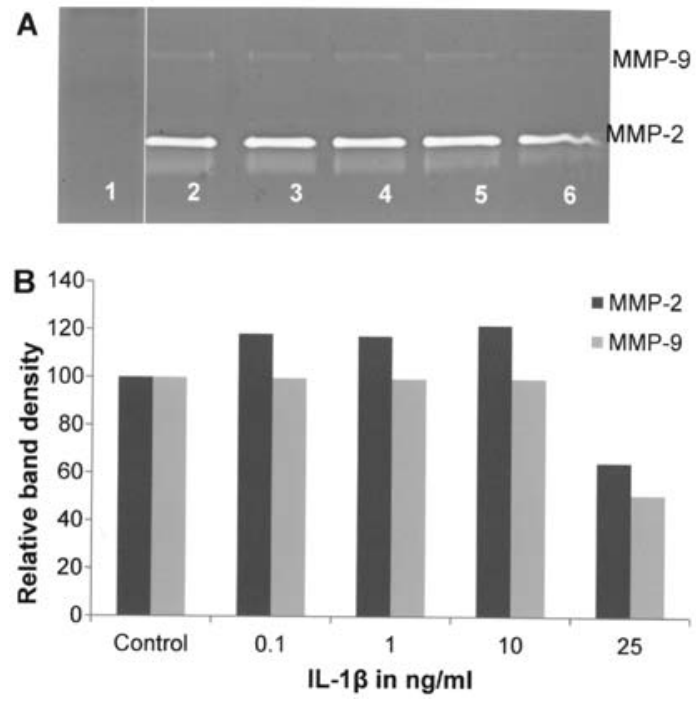

Figure 3. Effect of IL-1 $\beta$ on MMP-2 and -9 secretions in melanoma A-2058 cell line. (A) Gelatinase zymogram and (B) densitometry analysis of A-2058 MMP-2 and MMP-9 expressions. Lane 1, Markers; lane 2, Control; lanes 3-6, $\operatorname{IL}-1 \beta(0.1,1,10$ and $25 \mathrm{ng} / \mathrm{ml}$, respectively).

A
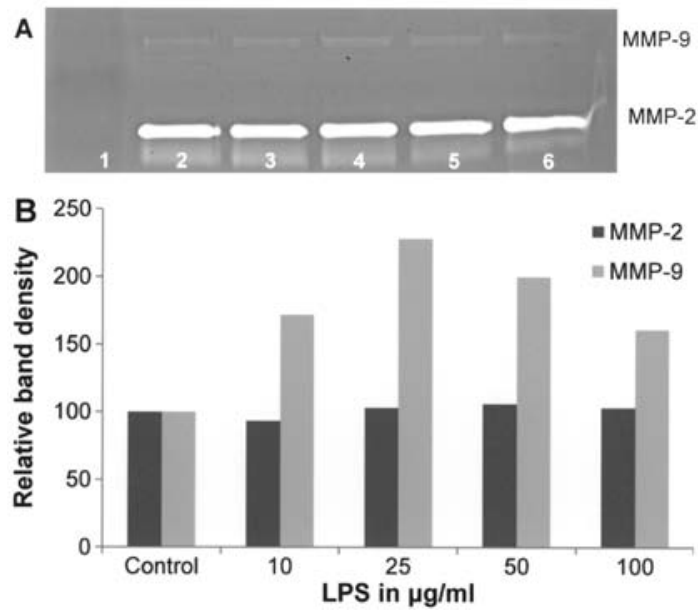

Figure 4. Effect of LPS on MMP-2 and -9 secretions in melanoma A-2058 cell line. (A) Gelatinase zymogram and (B) densitometry analysis of A-2058 MMP-2. Lane 1, markers; lane 2, Control; lanes 3-6, IL-1ß (0.1, 1, 10 and $25 \mathrm{ng} / \mathrm{ml}$, respectively).

Effect of TNF- $\alpha$ on A-2058 cell secretion of MMPs. On gelatinase zymography, A-2058 demonstrated strong expression of MMP-2 and slight expression of MMP-9. TNF- $\alpha$, used between 0.1-25 ng/ml, showed no significant overall effect on expression of MMP-2 (linear trend $\mathrm{R}^{2}=0.037$ ). TNF- $\alpha$ showed dose-dependent increased MMP-9 secretion (linear trend $\mathrm{R}^{2}=0.876$ ) with $200 \%$ of control at $25 \mathrm{ng} / \mathrm{ml}$ (Fig. 2).

Effect of IL-1 $\beta$ on A-2058 cell secretion of MMPs. Gelatinase zymography demonstrated strong expression of MMP-2 by A-2058 cells and slight expression of MMP-9. IL-1 $\beta$ at a concentration range of $0.1-25 \mathrm{ng} / \mathrm{ml}$ did not have significant effect on MMP-2 secretion by A-2058 cells, except at $25 \mathrm{ng} / \mathrm{ml}$ where MMP-2 level was reduced by $\sim 40 \%$ (linear trend $\left.\mathrm{R}^{2}=0.529\right)$. Also, MMP-9 secretion was not modified by IL-1 $\beta$ except for its $\sim 50 \%$ reduction at $25 \mathrm{ng} / \mathrm{ml}$ (Fig. 3). 
Table II. Effect of inhibitors on melanoma A-2058 MMP-2 and MMP-9 secretion.

PMA

Untreated $100 \mathrm{ng} / \mathrm{ml}$-treated

MMP-2 MMP-9 MMP-2 MMP-9

Treatment

(\%)

(\%)

$(\%)$

$(\%)$

Doxycycline $(\mu \mathrm{M})$

Co
10
25
50
100

$\begin{array}{cccc}100 & 100 & 100 & 100 \\ 89.8 & 99.3 & 102 & 122.6 \\ 89.2 & 105.5 & 95 & 111.2 \\ 66.5 & 97.9 & 69.8 & 68.7 \\ 28.3 & 70.1 & 33.2 & 29.5\end{array}$

EGCG $(\mu \mathrm{M})$

Control

10

25

50

100

$\mathrm{NM}(\mu \mathrm{g} / \mathrm{ml})$

Control

10

100

$\begin{array}{cccc}100 & 100 & 100 & 100 \\ 98.8 & 97.8 & 95.3 & 87.8 \\ 101.9 & 104.4 & 88.6 & 70.5 \\ 81.3 & 95.5 & 56.2 & 43.5 \\ 42.6 & 26.8 & 35 & 1\end{array}$

50

100

500

1,000

Actinomycin D ( $\mu \mathrm{g} / \mathrm{ml})$

Control

100

2

74.3

72.6

Cyclohexamide $(\mu \mathrm{g} / \mathrm{ml})$

Control

2

17.4

19.9

Dexamethasone $(\mu \mathrm{M})$

$$
\text { Control }
$$

50

Retinoic acid $(\mu \mathrm{M})$

Control

50

$\begin{array}{cc}100 & 100 \% \\ 119.9 & 87.7 \\ 82.8 & 17.4 \\ 42.3 & 14.4 \\ 13.1 & 2 \\ 4.1 & 1\end{array}$

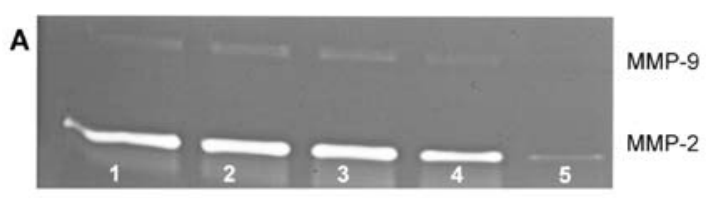

B
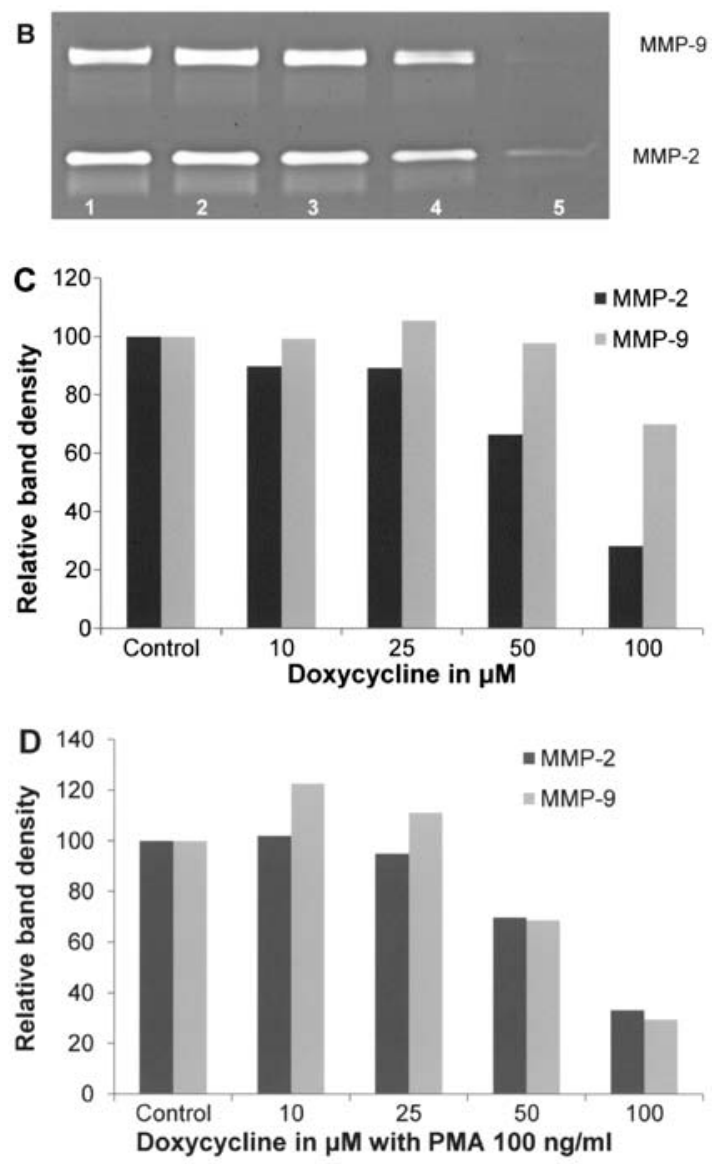

Figure 5. Effect of doxycycline on MMP-2 and -9 secretion by normal and PMA $100 \mathrm{ng} / \mathrm{ml}$-treated cells in melanoma A-2058 cell line. (A) Gelatinase zymograms of normal A-2058 cells and (B) PMA-treated A-2058 cells and densitometry analyses (C) of normal A-2058 cells and (D) PMA-treated A-2058 cells. Lane 1, Control; lanes 2-5, doxycycline (10, 25, 50 and $100 \mu \mathrm{M}$, respectively).

Chemical inhibitors. Table II shows the quantitative densitometry results from the effects of select chemical inhibitors doxycycline, dexamethasone, actinomycin D and cyclohexamide on MMP-2 and MMP-9 expression in melanoma A-2058 cell line.

Effect of doxycycline on A-2058 cell secretion of MMPs. Doxycycline inhibited MMP-2 secretion by A-2058 cells in a dose-dependent manner with $72 \%$ blockage at $100 \mu \mathrm{M}$ (linear trend $\mathrm{R}^{2}=0.843$ ). MMP-9 secretion was not affected by doxycycline up to $50 \mu \mathrm{M}$, and at $100 \mu \mathrm{M}$ it was decreased by $30 \%$ (linear trend $\mathrm{R}^{2}=0.480$ ). In the presence of PMA at $100 \mathrm{ng} / \mathrm{ml}$, doxycycline downregulated the expression of MMP-2 in a dosedependent manner, with $67 \%$ block $\left(\mathrm{R}^{2}=0.8072\right)$ at $100 \mu \mathrm{M}$ and $70 \%$ block (linear trend $\mathrm{R}^{2}=0.6711$ ) of MMP-9 at $100 \mu \mathrm{M}$ (Fig. 5).

Effect of actinomycin D on A-2058 cell secretion of MMPs.

Actinomycin D had moderate inhibitory effect on A-2058
Effect of LPS on A-2058 cell secretion of MMPs. Gelatinase zymography demonstrated strong expression of MMP-2 and slight expression of MMP-9 by A-2058 melanoma cells. LPS treatment between $10-100 \mu \mathrm{g} / \mathrm{ml}$ showed no significant effect on MMP-2 secretion (linear trend $\mathrm{R}^{2}=0.375$ ). However, enhanced MMP-9 secretion was observed at LPS up to $25 \mu \mathrm{g} / \mathrm{ml}$ that was followed by a decreased MMP-9 level (linear trend $\mathrm{R}^{2}=0.244$ ) (Fig. 4). 
A
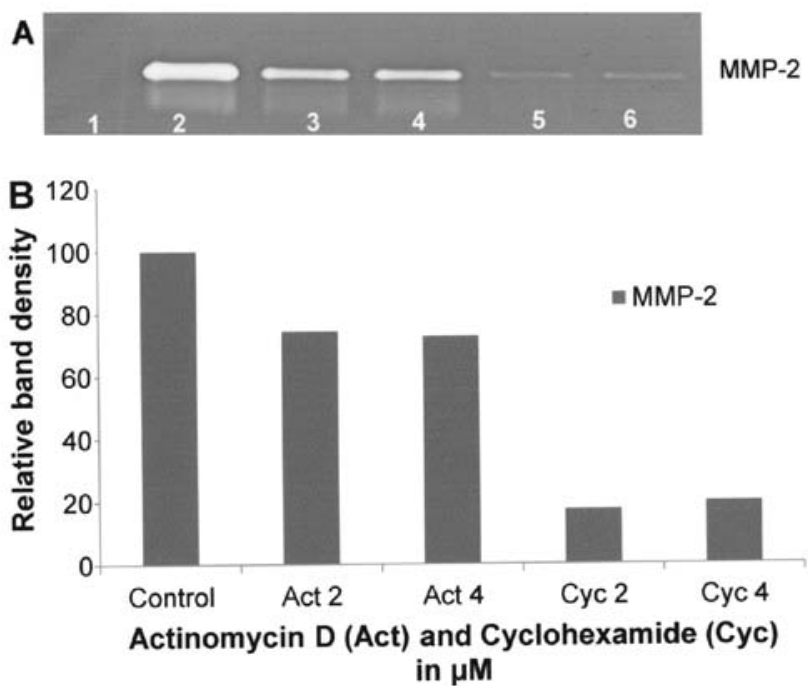

Figure 6. Effect of actinomycin D and cyclohexamide on MMP-2 secretion by normal cells in melanoma A-2058 cell line. (A) Gelatinase zymogram of normal A-2058 cells and (B) densitometry analysis. Lane 1, markers; lane 2, control; lanes 3 and 4 , actinomycin D ( 2 and $4 \mu \mathrm{M}$, respectively); lanes 5 and 6 , cyclohexamide ( 2 and $4 \mu \mathrm{M}$, respectively).

MMP-2 secretion $\left(\mathrm{R}^{2}=0.797\right)$ with 26 and $27 \%$ inhibition at 2 and $4 \mu \mathrm{M}$, respectively, as shown in Fig. 6.

Effect of cyclohexamide on A-2058 cell secretion of MMPs. Cyclohexamide had potent dose-dependent inhibitory effect on MMP-2 secretion, resulting in its inhibition by $80 \%$ at $4 \mu \mathrm{M}$ (linear trend $\mathrm{R} 2=0.727$ ), as shown in Fig. 6.

Effect of dexamethasone on A-2058 cell secretion of MMPs. Dexamethasone had slight stimulatory effect on MMP-2, with $107 \%$ of control at $50 \mu \mathrm{M}$ (data not shown).

Natural inhibitors. Table II shows the quantitative densitometry results, presenting the effects of natural compounds EGCG alone, the EGCG in a complex with other natural compounds (NM) and retinoic acid on MMP-2 and MMP-9 expression in melanoma A-2058 cells.

Effect of EGCG on A-2058 cell secretion of MMPs. Fig. 7 shows the effects of EGCG at 10, 25, 50 and $100 \mu \mathrm{M}$ concentrations on MMP-2 and MMP-9 secretions by unstimulated and PMA-stimulated A2058 melanoma cells. EGCG showed inhibitory effects on MMP-2 and -9 secretions by melanoma cells in a dose-dependent manner. In the presence of $100 \mu \mathrm{M}$ EGCG, the secretion of MMP-2 decreased by $57.4 \%$ (linear trend $\mathrm{R}^{2}=0.697$ ) and MMP-9 by $73.2 \%$ (linear trend $\mathrm{R}^{2}=0.519$ ), as shown in Fig. 7A and C. In the presence of PMA $(100 \mathrm{ng} / \mathrm{ml})$ the secretion of these enzymes was inhibited by EGCG in a dose-dependent manner. Slight inhibitory effect of EGCG on PMA-induced MMP-9 secretion was already observed at $25 \mu \mathrm{M}$ (30\% inhibition) and its total block at $100 \mu \mathrm{M}$ (linear trend $\mathrm{R}^{2}=0.901$ ), as shown in Fig. $7 \mathrm{~B}$ and $\mathrm{D}$.

Effect of NM on A-2058 cell secretion of MMPs. As shown in Fig. 8A and C, NM was effective in inhibiting secretion of MMP-2 by uninduced A-2058 cells in a dose-dependent
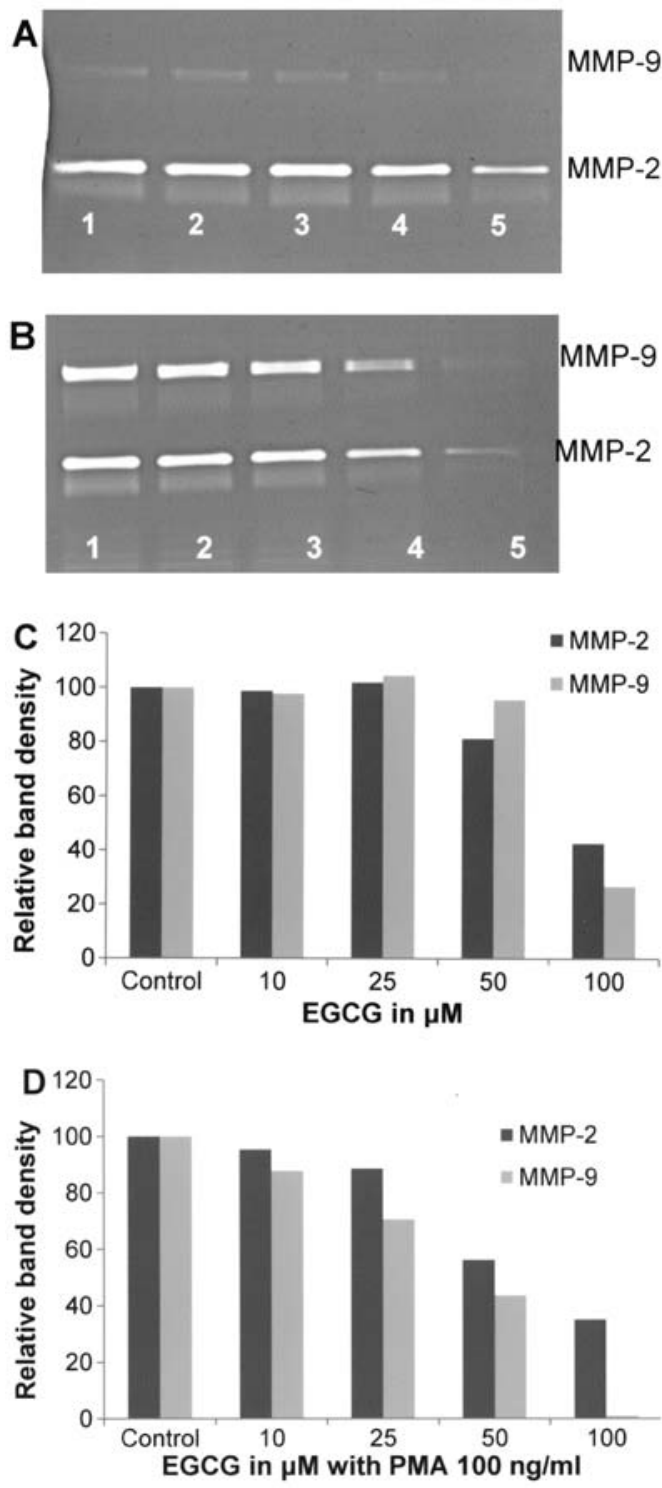

Figure 7. Effect of EGCG on MMP-2 and -9 secretion by normal and PMA $100 \mathrm{ng} / \mathrm{ml}$-treated cells in melanoma A-2058 cell line. (A) Gelatinase zymograms of normal A-2058 cells and (B) PMA-treated A-2058 cells and densitometry analyses (C) of normal A-2058 cells and (D) PMA-treated A-2058 cells. Lane 1, Control; lanes 2-5, EGCG (10, 25, 50 and $100 \mu \mathrm{M}$, respectively).

manner when used at 10,50,100, 500 and $1,000 \mu \mathrm{g} / \mathrm{ml}$ (linear trend $\mathrm{R}^{2}=0.868$ ) with virtual total block at $1,000 \mu \mathrm{g} / \mathrm{ml}$. NM also showed dose-dependent inhibition of MMP-2 and -9 expression in PMA-treated A-2058 cells as presented in Fig. 8B and D, which showed 96\% blockage of MMP-2 secretion at $1,000 \mu \mathrm{g} / \mathrm{ml}$ and total block of MMP-9 at $1,000 \mu \mathrm{g} / \mathrm{ml}$ (linear trends $\mathrm{R}^{2}=0.889$ and 0.818 , respectively).

Effect of retinoic acid on A-2058 cell secretion of MMPs. Retinoic acid inhibited A-2058 MMP-2 secretion with total block at $50 \mu \mathrm{M}$ (data not shown).

\section{Discussion}

Elevated MMP levels correlate with melanoma tumor progression, as documented in clinical studies $(5,6)$. Thus, knowledge 

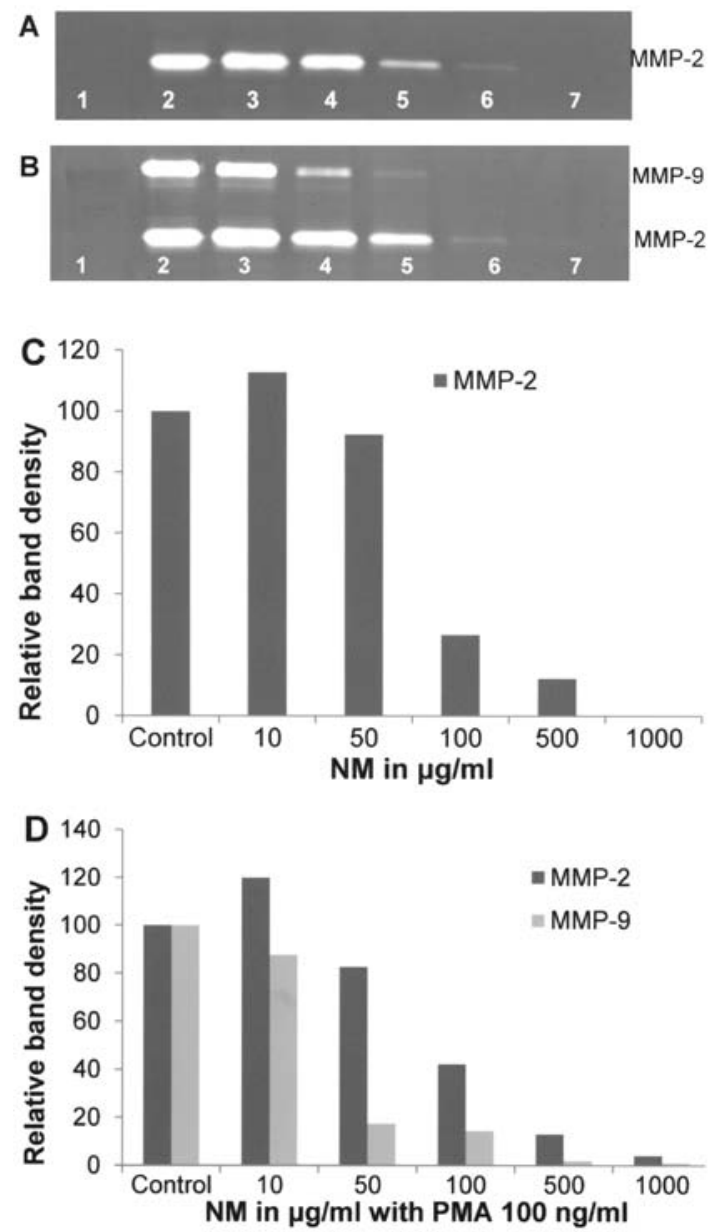

Figure 8. Effect of NM on MMP-2 and -9 secretion by normal and PMA $100 \mathrm{ng} / \mathrm{ml}$-treated cells in melanoma A-2058 cell line. (A) Gelatinase zymograms of normal A-2058 cells and (B) PMA-treated A-2058 cells and densitometry analyses (C) of normal A-2058 cells and (D) PMA-treated A-2058 cells. Lane 1, markers; lane 2, Control; lanes 3-7, NM (10, 50, 100, 500 and $1,000 \mu \mathrm{g} / \mathrm{ml}$, respectively).

of MMP regulation is of importance for developing therapeutic strategies for melanoma. Nikkola et al (5) found that melanoma patients with high-serum levels of MMP-9 had significantly poorer overall survival than patients with lower serum MMP-9 levels and that high MMP-9 levels were correlated with visceral or bone metastasis and presence of liver metastases. Malaponte et al (6) found that plasma levels of MMP-2 and TGF- $\beta$ in patients with primary melanoma were significantly higher than those of healthy controls and those significantly higher levels were found in patients with metastatic melanoma. Extracellular factors, such as the inflammatory cytokine IL-1 $\beta$ has been implicated in facilitating inflammation and melanoma tumor growth (10).

In the present study, we compared MMP secretion patterns in the presence of cytokines, PMA and LPS in melanoma A-2058 cells. In addition, we investigated the effect of inhibitors doxycycline, EGCG, NM and other compounds, such as dexamethasone, cyclohexamide, retinoic acid and agents that affect protein transcription and translation levels, such as actinomycin D. None of the tested inducers and cytokines was found to enhance MMP-2 secretion. PMA and TNF- $\alpha$ treatment showed potent dose-dependent upregulation of
MMP-9 secretion up to $400 \%$ that of control at $100 \mathrm{ng} / \mathrm{ml}$ PMA and $200 \%$ of control at $25 \mathrm{ng} / \mathrm{ml}$ TNF- $\alpha$. Surprisingly, IL-1 $\beta$ demonstrated no effect on MMP-9 secretion, except its decrease at $25 \mathrm{ng} / \mathrm{ml}$ and LPS showed no consistent effect, resulting in an upregulation and downregulation of MMP-9 secretion. Among tested inhibitors, chemical inhibitor doxycycline and natural inhibitors EGCG and NM with and without PMA treatment, potently downregulated the secretion of A-2058 MMP-2 and MMP-9 in a dose-dependent manner. MMP-2 secretion was potently inhibited by cyclohexamide and retinoic acid, moderately inhibited by actinomycin D and slightly stimulated by dexamethasome.

In addition to individual compounds we tested the effects of a specific nutrient mixture (NM) which has demonstrated anticancer efficacy in various in vitro and in vivo studies by affecting various mechanisms, including MMPs secretion (11). EGCG from green tea is one of its components, with green tea extract comprising $23 \%$ total NM weight. Another component is amino acid lysine, which is a natural inhibitor of plasmin-induced proteolysis, including MMPs $(12,13)$. Lysine also contributes to $23 \%$ of weight in NM. These and other compounds in NM (i.e. vitamin C, lysine, proline, copper, manganese and $\mathrm{N}$-acetyl cysteine) are important in supporting the integrity and stability of connective tissue through various mechanisms, thereby contributing to tumor encapsulation and curtailing cancer cells spread (14-22). In addition, NM components $\mathrm{N}$-acetyl cysteine and selenium have been shown to inhibit tumor cell MMP-9 and invasive activities and migration of endothelial cells through the ECM (23-25). Ascorbic acid has been documented to modulate cancer cell and tumor growth as well as to prevent metastasis (26-31) and low levels of ascorbic acid are found in cancer patients (32-34). The inhibitory effects of NM in comparison to EGCG alone on MMP-9 and MMP-2 secretion in unstimulated and PMA-stimulated A-2058 cells suggest enhancing effectiveness of EGCG when applied in a mixture with other natural compounds of similar and complementary mechanisms. The contribution of individual NM components towards inhibition of MMPs warrants further investigation.

In conclusion, our results showed that various inducers, cytokines, mitogens and inhibitors tested in this study modulate MMP-2 and -9 secretions by melanoma A-2058 cells. They suggest the clinical use of MMP inhibitors, especially potent and non-toxic ones as the nutrient mixture (NM) and its component EGCG in management of melanomas.

\section{Acknowledgements}

The present study was funded by the Dr. Rath Health Foundation (Santa Clara, CA), a non-profit organization.

\section{References}

1. ACS: Key statistics for melanoma skin cancer. http://www. cancer.org/cancer/skincancer-melanoma/detailedguide/melanomaskin-cancer-key-statistics. Last revised: 05/20/2016, Accessed $12 / 12 / 16$

2. Yurchenco PD and Schittny JC: Molecular architecture of basement membranes. FASEB J 4: 1577-1590, 1990.

3. Barsky SH, Siegal GP, Jannotta F and Liotta LA: Loss of basement membrane components by invasive tumors but not by their benign counterparts. Lab Invest 49: 140-147, 1983. 
4. Liotta LA, Tryggvason K, Garbisa S, Hart I, Foltz CM and Shafie S: Metastatic potential correlates with enzymatic degradation of basement membrane collagen. Nature 284: 67-68, 1980

5. Nikkola J, Vihinen P, Vuoristo MS, Kellokumpu-Lehtinen P, Kähäri VM and Pyrhönen S: High serum levels of matrix metalloproteinase- 9 and matrix metalloproteinase-1 are associated with rapid progression in patients with metastatic melanoma. Clin Cancer Res 11: 5158-5166, 2005.

6. Malaponte G, Zacchia A, Bevelacqua Y, Marconi A, Perrotta R, Mazzarino MC, Cardile V and Stivala F: Co-regulated expression of matrix metalloproteinase- 2 and transforming growth factor- $\beta$ in melanoma development and progression. Oncol Rep 24: 81-87, 2010

7. de Visser KE and Coussens LM: The inflammatory tumor microenvironment and its impact on cancer development. Contrib Microbiol 13: 118-137, 2006.

8. Coussens LM and Werb Z: Inflammation and cancer. Nature 420 $860-867,2002$.

9. Mantovani A, Allavena P, Sica A and Balkwill F: Cancer-related inflammation. Nature 454: 436-444, 2008.

10. Qin Y, Ekmekcioglu S, Liu P, Duncan LM, Lizée G, Poindexter N and Grimm EA: Constitutive aberrant endogenous interleukin-1 facilitates inflammation and growth in human melanoma. Mol Cancer Res 9: 1537-1550, 2011.

11. Niedzwiecki A, Roomi MW, Kalinovsky T and Rath M: Micronutrient synergy: a new tool in effective control of metastasis and other key mechanisms of cancer. Cancer Metastasis Rev 29: 529-542, 2010.

12. Rath M and Pauling L: Plasmin-induced proteolysis and the role of apoprotein(a), lysine and synthetic analogs. Orthomolecular Med 7: 17-23, 1992

13. Sun Z, Chen YH, Wang P, Zhang J, Gurewich V, Zhang P and Liu JN: The blockage of the high-affinity lysine binding sites of plasminogen by EACA significantly inhibits prourokinaseinduced plasminogen activation. Biochim Biophys Acta 1596: 182-192, 2002.

14. Mussini E, Hutton JJ Jr and Udenfriend S: Collagen proline hydroxylase in wound healing, granuloma formation, scurvy, and growth. Science 157: 927-929, 1967.

15. Kivirikko KI and Myllylä R: Collagen glycosyltransferases. Int Rev Connect Tissue Res 8: 23-72, 1979.

16. Valcic S, Timmermann BN, Alberts DS, Wächter GA, Krutzsch M, Wymer J and Guillén JM: Inhibitory effect of six green tea catechins and caffeine on the growth of four selected human tumor cell lines. Anticancer Drugs 7: 461-468, 1996.

17. Mukhtar H and Ahmad N: Tea polyphenols: Prevention of cancer and optimizing health. Am J Clin Nutr 71 (Suppl): 1698S-1702S discussion 1703S-1704S, 2000.

18. Yang GY, Liao J, Kim K, Yurkow EJ and Yang CS: Inhibition of growth and induction of apoptosis in human cancer cell lines by tea polyphenols. Carcinogenesis 19: 611-616, 1998.

19. Taniguchi S, Fujiki H, Kobayashi H, Go H, Miyado K, Sadano H and Shimokawa R: Effect of (-)-epigallocatechin gallate, the main constituent of green tea, on lung metastasis with mouse B16 melanoma cell lines. Cancer Lett 65: 51-54, 1992.

20. Hara Y: Green tea: Health Benefits and Applications. Marcel Dekker, New York, Basel, 2001. https://doi.org/10.1201/ 9780203907993
21. Gupta S, Hastak K, Afaq F, Ahmad N and Mukhtar H: Essential role of caspases in epigallocatechin-3-gallate-mediated inhibition of nuclear factor kappa B and induction of apoptosis. Oncogene 23: 2507-2522, 2004.

22. Fujiki H, Suganuma M, Okabe S, Sueoka E, Suga K, Imai K, Nakachi K and Kimura S: Mechanistic findings of green tea as cancer preventive for humans. Proc Soc Exp Biol Med 220: 225-228, 1999.

23. Kawakami S, Kageyama Y, Fujii Y, Kihara K and Oshima H: Inhibitory effect of N-acetylcysteine on invasion and MMP-9 production of T24 human bladder cancer cells. Anticancer Res 21: 213-219, 2001.

24. Morini M, Cai T, Aluigi MG, Noonan DM, Masiello L, De Flora S, D'Agostini F, Albini A and Fassina G: The role of the thiol $\mathrm{N}$-acetylcysteine in the prevention of tumor invasion and angiogenesis. Int J Biol Markers 14: 268-271, 1999.

25. Yoon SO, Kim MM and Chung AS: Inhibitory effect of selenite on invasion of HT1080 tumor cells. J Biol Chem 276: 20085-20092, 2001

26. Cha J, Roomi MW, Ivanov V, Kalinovsky T, Niedzwiecki A and Rath M: Ascorbate supplementation inhibits growth and metastasis of B16FO melanoma and 4T1 breast cancer cells in vitamin C-deficient mice. Int J Oncol 42: 55-64, 2013.

27. Naidu KA, Karl RC, Naidu KA and Coppola D: Antiproliferative and proapoptotic effect of ascorbyl stearate in human pancreatic cancer cells: Association with decreased expression of insulinlike growth factor 1 receptor. Dig Dis Sci 48: 230-237, 2003.

28. Anthony HM and Schorah CJ: Severe hypovitaminosis C in lungcancer patients: The utilization of vitamin $\mathrm{C}$ in surgical repair and lymphocyte-related host resistance. Br J Cancer 46: 354-367, 1982.

29. Maramag C, Menon M, Balaji KC, Reddy PG and Laxmanan S: Effect of vitamin $C$ on prostate cancer cells in vitro: Effect on cell number, viability, and DNA synthesis. Prostate 32: 188-195, 1997.

30. Koh WS, Lee SJ, Lee H, Park C, Park MH, Kim WS, Yoon SS, Park K, Hong SI, Chung MH, et al: Differential effects and transport kinetics of ascorbate derivatives in leukemic cell lines. Anticancer Res 18: 2487-2493, 1998

31. Chen Q, Espey MG, Krishna MC, Mitchell JB, Corpe CP, Buettner GR, Shacter E and Levine M: Pharmacologic ascorbic acid concentrations selectively kill cancer cells: Action as a pro-drug to deliver hydrogen peroxide to tissues. Proc Natl Acad Sci USA 102: 13604-13609, 2005.

32. Núñez Martín C, Ortiz de Apodaca y Ruiz A and Ruiz A: Ascorbic acid in the plasma and blood cells of women with breast cancer. The effect of the consumption of food with an elevated content of this vitamin. Nutr Hosp 10: 368-372, 1995 (In Spanish).

33. Kurbacher CM, Wagner U, Kolster B, Andreotti PE, Krebs D and Bruckner HW: Ascorbic acid (vitamin C) improves the antineoplastic activity of doxorubicin, cisplatin, and paclitaxel in human breast carcinoma cells in vitro. Cancer Lett 103: 183-189, 1996

34. Cooke JP and Dzau VJ: Nitric oxide synthase: Role in the genesis of vascular disease. Annu Rev Med 48: 489-509, 1997. 